\title{
THE PIOUS PEOPLE GIVEN THE RIGH'T TO THE PROMISED LAND IN INDONESIAN COMMENTARY
}

\author{
Fredrik Y. A. Doeka \\ The Theological Faculty of Artha Wacana Christian University - Kupang \\ Email: fredrikyadoeka@yahoo.co.uk
}

\begin{abstract}
Abstrak
Para teolog Indonesia menyatakan, babwa negara Israel tidak memiliki hak untuk mengklaim secara politik, babwa Tanab Pejanjian adalah milik mereka yang didasarkan pada apa yang tertulis di dalam Torah. Bagi tafsir Islam dan Kristen Indonesia, selurub bumi adalab milik Allab. Karna itu Allab dapat memberikan tanah ini keppada siapa saja yang berlaku adil, mencintai kesetiaan, dan bidup dengan rendab bati dan yang berserah diri kepada Allab.
\end{abstract}

مerich

وأى جميع أهل الألوهية الإندنسية أن دولة إسرائيل ها بها حق سياسي أن أرض الميثاق لها على

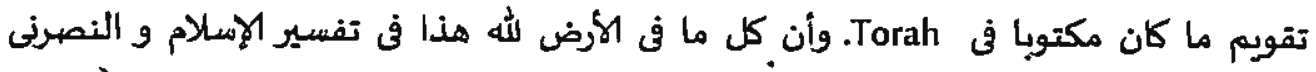

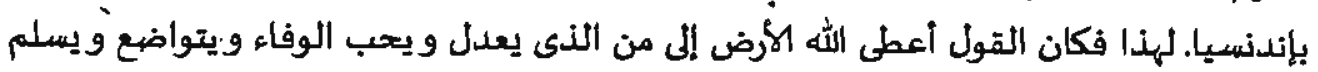
نقعسه الله.

Keywords: The Promised Land, Istael, Al-Qur'an, the Old Testament.

\section{A. Introduction}

The Promised Land has become a sensitive issue in the wotld up to now. This issue is often the subject of keen analysis in Indonesia. A map titled: The Land of Jens and Palestinians 1946-2000 depicts the forceful actions of Israel in occupying the land of the Palestinians. That map published in Stuara Pembaruan, a national 
Christian newspaper, showing the expansion of Israel over a 54-year period. In relation to this map, Weinata Sairin, the vice general secretary of the Communion of Churches in Indonesian (PGI), commented that that the root of war between Israel and Hammas-Palestine is the Promised Land. He also adds that the Bible it is written that this Land was truly given to the people of Moses. However, there are different interpretations over what makes up the biblical Israel and the present political state of Israel. ${ }^{1}$

The Jews have always claimed that God gave the Promised Land to the children of Israel as stated in the Torah given by Moses. But Palestinian-Arabs say that this land which has now been taken over by the Jews actually belongs to their ancestors who have lived there continuously over many centuries and has 'been passed on from generation to generation. ${ }^{2}$

Some Indonesian Islamic and Christian scholars also give much attention to this issue. More than that their commentary has automatically become an important referènce in Indonesia. In this paper, we will start our exploration of the issue of the Promised Land as seen by the three key Islamic interpreters: Haji Abdul Malik Bin Abdul Karim Amirullah, the RI Departement of Religious Affairs, and Muhammad Quraish Shihab. Why Hamka? Because he represents a contextual thinking in his commentary. Why the Departement of Religious Affairs? This is a ministry that involves many Islamic scholars from various traditions. Why Muhammad Quraish Shihab? He represents modern Indonesian Islamic thinking.

Moreover, we will also elaborate two views presented by the Christian theologians; Sri Wismoady Wahono and Yongky Karman. Sti Wismoady Wahono because he represents ecumenical thinking, although he himself is strongly influenced by the views of the Gereja Kristen Jawi Wetan (a church which strongly preserves Javenese tradition). Yongky Karman because he is a minister of the Gereja Kristen SETTA that is close to the established churches

${ }^{1}$ Daily Newspaper, Suara Penbaruan, Rabu 21 Januari 2009: A3 (supplement page).

2 Elias P. Pohan, "Teologi Pembebasan Palestina; Suatu Deskripsi Ringkas Sejarah Kelahiran dan Isinya" "The Palestinian Liberation Theology, A Brief Description on its Bom and Content] in Jumal Penuntum, vol. 3, No. 10, January 2007, p. 241-248. 
of the evangelical mainstream and his views are fairly representative of this background.

\section{B. The Muslim Interpreters}

Haji Abdul Malik Bin Abdul Karim Aminullab (1908-1981), better known under acronym of HAMKA is a twentieth century Indonesian Muslim scholar. One of his many books is Tafsir Al-Azbar, a thirty-volume commentary on the Qur'an. He admitted that Fi Zilal al-Qur'an [In the shade of the Qur'an] of Sayyid Qutb (1906-1966, a fairly radical leader of the Muslim Brotherhood) had influenced him in the composition of this commentary. ${ }^{3}$

In his Tafsir, Hamka pays much interest to the sura 7,137:

And We made a people, considered weak (and of no account), inheritors of lands in both east and west, - lands whereon Wi sent down Our blessings. The fair promise of thy Lord was fulfilled for the Children of Israel, becatse they bad patience and constancy, and We levelled to the ground the great works and fine buildings which Pharaoh and bis people erected (with such pride).

Hamka interprets this verse in the Tafsir Al-Azhar to mean that God gave to the people of Moses the Promised Land, namely Sham or Syrian territory spreading out from the eastern border of the Syrian land, to the West, the border of Egypt, including the land of Palestine: ${ }^{4}$ In another place, he cites Genesis 12,7: The LORD appeared to Abraham and said: "To your offspring I will give this land."

Saying that, the Promised Land (ardhul miad) was given to Abraham's offspring (sura 5:21). As it is known, Abraham had two sons, Ishmael and Isaac. Ishmael and his children have already been living in the land of Hijaz and they were growing as a big people, namely the Arab people. In the meantime the people of Israel, Isaac's children, had occupied the Promised Land after four hundred years at the era of Moses. ${ }^{5}$

${ }^{3}$ Hamka, Tafsir A/Aqbar, (Jakarta: Panjimas 2005), I: 55.

${ }^{4}$ Hamika, Tafsir Al Aqbar, (Jakarta: Panjimas 2005), IX: 2005: 49

${ }^{5}$ Hamka, Tafsir Al Aqbar, (Jakarta: Panjimas 2000), VI: 203. 
Again, according to Hamka, Moses' people just enjoyed the land for a short time. This is the result of the fact that the children of Israel did not live piously before God. ${ }^{6}$ During the next pertiod of history, nations such as Babel, Persia, Rome, and Arabia occupied the land one after the other. For 1.400 years the land was under the control of Arabs. However, in 1948, Jews supported by Great Britain and the United States took possession of it because they claimed that their right to ownership dated back to 2500 B.C. As a consequence of this action nearly two million Arabs (the indiginous population) were chased from their land. Since then the Jews have lived, not dispersed over the whole world, but also in Arab territory. For Hamka, the Jews have been sinners until the present and because of this their special right to ownership of the land has been taken away (sura 7:167). Hamka quotes in full 7:167,

Your Lord proclaimed that He would until the Day of Resurrection send forth against them those who would afflict them with the worst evil of suffering. After they conquered this land in 1948, they attacked the other Arab countries again in 1967, and in 1969 they set fire in the Al Aqsa mosque. At that time the Arab citizens of Palestine revolted under the leadership of Yasir Arafat. They asked for remuneration and promised that they would never stop fighting before Palestine citizens themselves have chased away the Jews from this land. ${ }^{7}$

Moreover, Hamka says that all Muslims in the world have a compulsory duty to take the land back and give it to the Arabs. His argument is that God owns this earth. Furthermore, God wills to give it to those people who surrender to Him. Thus the protest meetings and other actions, which have grown in number and are executed by Yaser Arafat's followers [or by Hammas' followers nowadays] because their region has been occupied by the Jews, are essentially a response to God's will.

Departemen Agama RI. In 1965 Departemen Agama RI (the Ministry of Religion of the Indonesian Republic) ${ }^{9}$ published an Indonesian translation of

${ }^{6}$ Hamka, Tofsir Al Aqbar, IX: 141.

${ }^{7}$ Hamka, Tafsir AlAzbar, LX: 151.

${ }^{8}$ Hanka, Tafsir AlAqpar, IX: 50, 151.

${ }^{9}$ B. J. Boland gives some significant notes on Departemen Agama RI [the religious Affairs Department of R] in his book, The Struggle of Islam in Modem Indoneria, (Leiden: KITLV 1982), especially section 4 of the chapter 2: 104-112. 
the Qur'an. In 1975 (in the second step of a series of five-year Development Plans), Departemen Agama RI published Al Qur'an dan Tafsimya [The Qur'an and its commentary]. This commentary has eleven volumes, the first volume being an introduction and the others, a running Qur'anic commentary.

Departemen Agama sees the Promised Land as encompassing a larger territory than Hamka speaks of. That area consists of Syria (Syam) to Egypt and all the lands ever colonized by Pharaoh that were also given to the people of Israel as mentioned in sura 7,137 :

And We made a people, considered weak (and of no account), inberitors of lands in both east and west, - lands whereon We sent doun Our blessings. The fair promise of thy Lord was fulfilled for the Children of Israel, because they bad patience and constancy, and We levelled to the grownd the great works and fine buildings which Pharaob and bis people erected (with such pride).

This gift was consequent upon the patience of the people of Istael in waiting for the fulfilment of God's promise. ${ }^{10}$ Elsewhere it is said that the gift of the Promised Land is God's reward to the children of Israel because they had suffered so much under the tyranny of Pharaoh. In the commentary of the Promised Land of sura 28,5-6:

And We wished to be Gracious to thase wbo were being depressed (oppressed?????) in the land, to make them leaders (in Faith) and make them heirs, To establish a firm place for them in the land, and to show Pharaob, Haman, and their bosts, at their bands, the very things against which they were taking precautions,

Departemen Agama writes:

... Allah mewariskan kepada mereka negeri Syam dengan menjadikan mereka berkuasa di sana ... Allab mevariskan pula negeri Mesir ...

[God gave the territory of Syam and made them (the Children of Israel) ruled over there ... Also God gave the territory of Egypt ... ].11

Muhammad Quraish Shibab. Shihab was born in Rappang-South Sulawesi, on the $16^{\text {th }}$ February, 1944. Among his works, Shihab's most well-known work is Tafsir AL-Misbbab. He elaborates the content of the Qur'an in a truly fascinating

10 Departemen Agama RI, Al-Qur'an dat Tafsimya, ( Jakarta: Departemen Agama RI 1997/1998), III , 7-8-9: 563-564.

11 Departemen Agama RI, ALQur'an dan Tafsimya, VII, 19-20-21: 310. 
arid very understandable manner. The work is written in 15 volumes and is meant to introduce the Qur'an to ordinary readers. ${ }^{12}$

In the discussion to the sura 7,128 :

Moses said to bis people: "Pray for belp from Allab, and (tvait) in patience and constancy: for the earth is Allah.s, to give as a beritage to such of His servants as He pleasetb; and the end is (best) for the righteous,

He says first theologically that the whole world is only God's possession, but also that the land was actually promised to the Jews. However, they had to be a pious people (orang-orang taqwa). They would enjoy the land, not only for a short time, but also for the remainder of the existence of this world. ${ }^{13}$ He cites some Islamic scholars mentioning two opinions in connection to the wordings in sura 28:5, menjadikan mereka orang-orang yang mesvarisi [make them heirs]. Some say that these words refer to ruling the territories that were occupied by Pharaoh before. On the contrary, the others explain that after the death of Pharaoh and the crossing of the Red Sea, the people of Israel did not go back to the Egypt but stayed in Palestine and never returned to their hometown. They settled themselves to rule in Palestine. ${ }^{14}$

\section{The Christian Interpreters}

Sni Wismoady Wabono (1944-2002). Wahono was a professor in Old Testament studies in the Jakarta Theological Seminary for some years, until his church called him to lead the Synod of Gereja Kristeri Jawi Wetan [the Christian Church of Jawi Wetan] as its moderator. Throughout his cateer, he was involved in Islam - Christian dialogie in East Java. One of the many accademic works he produced is Israel: Pokok Sepanjang Sejarah [Israel: the subject of A Long history].

${ }^{12}$ M. Quraysh Shihab, Tafsir Al-Misbbab; Pesan, Kesan dan Keserasian Al-Qur'ān [Al-Mishbah Interpretation; Message, Impression and Harmony of Qur'ān Volume 1], (Jakarta: Lentera Hati 2006), 1: ix-x.

${ }^{13}$ M. Quraish Shihab, Al-Mishbah, (Jakarta: Lentera Hati 2006), 5: 215.

${ }^{14}$ M. Quraish Shihab, Al-Misbbah, (Jakarta: Lentera Hati 2006), 10: 309. 
In his writing about Israel: Pokok Sepanjang Sejarah published in the Journal PENUNTUN, vol. 3, No. 10, January 2007, Wismoady refers to the land according to its many names throughout the length of its history. It is named the land of Canaan because the people of Kenite had once occupied that region. It is also refered to as the land of Palestine because Palestinian people lived there. It is refered to as the land of Israel because it was settled by the people of Israel and also as the Promised Land because God promised it to the people of Moses.

Now, Christians, Muslims and Jews all claim together that this land is their Holy Land. This identification, which is part of their religious selfunderstanding, is often used to justify the political claim, whereas it could and should be used to offer a new approach to finding a peaceful solution to the political crisis in the Middle East. Therefore, according to Wismoady, whether $\mathrm{Jews}^{15}$ or Palestinians own the land, they should offer trouble-free access for these three Semitic religions for the purpose of religious observations and pilgrimage. ${ }^{16}$

Yongky Karman obtained his Ph.D. degree in the Evangelische Theologische - Faculteit, Leuven - Belgium 2004. Now he is a lecturer in Old Testament in STT Cipanas (the Cipanas Theological Seminary), West Java. Since 2005, he has become a part time lecturer in the doctorate program at STT Jakarta (the Jakarta Theological Seminary). One of his many scientific writings is Konflik Israel-Palestina dari Kacamata Kristen [The Conflict between Israel and Palestine From the Christian Perspective], which was presented at the seminar "Konflik Israel-Palestina: Perang Sampai Kapan?" in STT Jakarta in $22^{\text {nd }}$ of January 2009.

He starts to explore the issue of Promised Land with three questions. Does it legitimate the religious claim that the Palestine territory is the inheritance of the Jews? Does it legitimate that present ownership should be based on past ownership of the land? Given the Old Testament account of how the Children

${ }^{15}$ About the Istael at now, Wismoady sees that they are Yehuda tribe, one of 12 (or 13) Israel tribes, that are mentioned by the New Testament as the Jews. Jumal Penuntwn, vol. 3 , No. 10, January 2007: 237.

16 Ibid: 238-239. 
of Israel seized the land from the people of Canaan can Israel and Joshua be legitimately refered to as colonizers? For Karman, the religious claims of Israel to ownership of the land cannot be justified. On this, he gives three reasons.

First, present day Jews are not so easily identified as the descendants of the people of Isreal in the Old Testament. After the exile of Babylonia, the children of Israel could not claim the Promised Land as their own. First, the land was a province of the Persian empire. Afterwards it became part of the Greek and then the Roman empires under the governance of occupying forces. The Jews, being aware of this history, had no thought of reconquering the land for almost two thousand years.

The second reason is based on the fact that land borders change from time to time. Karman cites a number of the Old Testament verses as proof of this. For instance, he mentions six different biblical versions describing the geographical boundaries of the promised land. To attempt to use these references as a basis to define the precise area which comprises what is understood to be the Promised Land is simply much to complicated.

The first version states that it takes in the area from the border from Egypt to the bank of the Euphrates river (Genesis 15:18), from the Red sea to the Palestine sea, from the desert to River Euphrates (Exodus 23:31); the second versions states that the region stretches from the desert to the mountains of Lebanon, from the River Euphrates to the Great sea in the West (Deuteronomy 11:24; Joshua 1:14). The third, that it covers the area from the Amorite mountain range, to the coast i.e. the region of Canaan, from the mountains of Lebanon to the River Euphrates (Deuteronomy 1:7; cf. Proverbs 2:9 and Genesis 48:22). Fourtbly, the whole region of Canaan that is very obviously identified in Numbers 34:1-12. "Your south side shall be from the wildemess of Zin along the side of Edom, and your southem boundary shall be from the end of the Dead sea on the East, and your boundary shall turn south on the ascent of Akrabim, and cross to Zin, and its end shall be the south of Kadesh-Barnea. Then it shall go on to Ha'zar-ad'dar, and pass along to Azmon to the Brook of Egypt, and its termination shall be at the sea." The West is from Hamat to Zedad, reaching Zifron and ending at Hazar-Enan. The Eastern boundary is 
from Hazar-Enan to Shepham, to Riblah on the East side of A'in until Sea of Chin'neret in the East, reaching down to the River Jordan and ending at the Dead Sea. The fifth version is based on the account that under Joshua's leadership it was indicated that the whole Promised Land was to be possessed by the children of Israel (Joshua 21:43-45). Sixthly, whenever King Salomon ruled, the borders of land stretched further than before (1 Kings 4:24-25/5:4-5). On the whole, as he underlines, a map of the land may be roughly represented by a circle encompassing the region from North Africa (Egypt) to West Asia (the Arabian desert, Iraq and Iran). These territories mentioned in the Bible lie in the intersection of two main regions i.e. Persia and Egypt.

In his final reason, Karman states that the brutal invasion of the Palestinian territories by Israeli troops cannot be said to be absolutely in line with the will of God. If God has willed the land for the Jews, it should be given in a peaceful way because the awaited Messiah, the king of the Jews, who will be sent to them by God, is the peaceful king (Zechariah 9:9). Therefore, God will give the land to Moses' people according to His attributes that are gentle and fair. $\mathrm{He}$ therefore concludes that there can be no religious justification by the state of Israel for its actions.

\section{Conclusion}

According to Indonesian commentary, the modern State of Israel has no right to make any political claim over the Palestine territories based upon what is written in the Torah. Further their commentary reminds us that the whole earth belongs to God (Cf. Leviticus 25:23, Psalm 24:1), He can give this land, not only to Israel but also to other nations who do justice, love kindness and walk humby with their God (cf. Micah 6:8). For this reason the Promised Land should be an open territory for all peoples to live together there in peace (Ezekiel 47:21-23). Therefore, both the Palestinian-Arabs and Jews, or let us say the three communities of faith: Muslims, Christians and Jews. of the region when they talk about their claim to ownership of the Promised Land should realize their equal status, right and responsibility to create a peaceful solution. The Qur'an itself highly respects the Jews as mentioned in.the sura 3:64: ya abl 
al-Kitab ta'alaw ila kalimab sawa [O people of Book! Come to common terms]. Based on this verse, therefore, Muslims, Christians and Jews in the Middle East should establish dialogue and reconciliation after the conflicts of so many centuries. $^{17}$

Those who desire to create dialogue and reconciliation most surely hold the moral high ground for those of us who long to see world peace. Who amongst us has the moral courage to take these brave steps? Wallahu a'lam (God's knowledge is higher).

\section{BIBLIOGRAPHY}

Abdullah, Zulkarnaini. 2007. Yabudi dalam Al-Qur'an; Teks, Konteks \& Diskursus Agama Jews in the Qur'an; The Text, Context \& Religious Discourse], Jakarta: eLSAQ Press.

Boland, B. J..1982. The Struggle of Islam in Modem Indonesia, Leiden: KITLV.

Daily Newspaper, Suara Pembarzan, Rabu 21 Januari 2009: A3 (supplement page).

Departemen Agama RI.1997/1998. Al-Qur'an dan Tafsimya Jilid III Juz 7-8-9, Jakarta: Departemen Agama RI.

Departemen Agama RI.1997/1998 Al-Qur'an dan Tafsimya Jilid VII Juz 19-2021, Jakarta: Departemen Agama RI.

Hamka.2000. Tafsir $A l$ Azbar Juz VI, Jakarta: Panjimas.

Hamka. 2005. Tafsir Al Azhar Juz I, Jakarta: Panjimas.

Hamka.2005. Tafsir Al Azbar Juz IX, Jakarta: Panjimas.

Karman, Yongky.2009. "Konflik .Israel-Palestina dari Kacamata Kristen"

[Conflict between Israel and Palestine according to Christian View], Paper which was presented at the seminar "Konflik Israel-Palestina: Perang .

17Zulkarnaini Abdullah, Yabudi dalam Al-Qur'an; Teks, Konteks do Diskursus Agama Jews in the Qur'ān; The Text, Context \& Religious Discourse], (Jakarta: eLSAQ Press 2007),p. 12. 
Sampai Kapan?" in the Jakarta Theological Seminary in $22^{\text {ad }}$ of January 2009.

Shihab, M. Quraish. 2006.Tafsir Al-Misbbab; Pesan, Kesan dan Keserasian Al-Qur'an Volume 1 [A1-Mishbah Interpretation; Message, Impression and Harmony of Qur'an Volume 1], Jakarta: Lentera Hati.

Shihab, M. Quraish. 2006. Al-Misbbab Volume 5, Jakarta: Lentera Hati.

Shihab, M. Quraish. 2006. Al-Mishbab Volume 10, Jakarta: Lentera Hati.

Wahono, Sti Wismoady.2007.“Israel: Pokok Sepanjang Sejarah” [Israel: the subject of all history long] published by the Journal PENUNIUN, vol. 3, No. 10, January. 